Open Access

\title{
Understanding STEM teacher learning in an informal setting: a case study of a novice STEM teacher
}

Mi Song Kim ${ }^{*}$ and Najmeh Keyhani

\author{
* Correspondence: misong.kim@ \\ gmail.com \\ University of Western Ontario, \\ London, Ontario, Canada
}

\begin{abstract}
Research into informal STEM education over the past years has shown that informal learning environments increase students' learning in STEM. However, how STEM teachers learn in an informal setting remains unclear. Such educators who work in informal settings are not all required to have undergone teacher education or professional development, and their progress may differ from other teachers' experiences. As a result, it is important to observe and understand the path such teachers take to see how they develop their teacher identities. Drawing upon Baxter Magolda's (Making their own way: Narratives for transforming higher education to promote self-development, 2004) self-authorship framework, this qualitative case study explores the progress of one informal STEM teacher throughout her first class by qualitatively analyzing her journals, lesson plans, and artifacts. The teacher's journey progresses towards self-authorship in a nonlinear way with multiple signs of the epistemological, intrapersonal, and interpersonal dimensions of the framework being deeply interconnected to one another. Implications for STEM teacher education within the context of informal STEM education are discussed.
\end{abstract}

Keywords: STEM teacher learning, Informal setting, Self-authorship

\section{Introduction}

Research on informal STEM education over the last 10 years or so has indicated that informal learning environments help increase students' learning in STEM (Ghadiri Khanaposhtani, Liu, Gottesman, Shepardson, \& Pijanowski, 2018; Mohr-Schroeder et al., 2014). As a result, much effort has been put into promoting student participation in STEM-focused informal education activities in many countries around the world including Canada and the USA (Kim, 2017). Clearly, creating a STEM-literate society is closely linked to education, and a main component of this education is the STEM teachers involved. Hence, emphasis on STEM teacher education is also increasing (Du et al., 2019; Milner-Bolotin, 2018; Richmond et al., 2017; Rinke, GladstoneBrown, Kinlaw, \& Cappiello, 2016; Terrazas-Marín, 2018; Wright, Balgopal, Sample McMeeking, \& Weinberg, 2019) and much research is being carried out on a wide range of aspects related to both pre- and in-service STEM teachers. However, understanding STEM teacher learning in informal settings such as STEM centers, science centers, and museums remains an area less talked about in the literature.

(c) The Author(s). 2019 Open Access This article is distributed under the terms of the Creative Commons Attribution 4.0 International License (http://creativecommons.org/licenses/by/4.0/), which permits unrestricted use, distribution, and reproduction in any medium, provided you give appropriate credit to the original author(s) and the source, provide a link to the Creative Commons license, and indicate if changes were made. 
A challenge often mentioned for STEM teachers is that their environment and work are heavily dependent on technology while technology is constantly changing and evolving (Waight \& Abd-El-Khalick, 2012). Not much is known on how informal STEM teachers progress in such environments and how or whether this changing nature of technology enhances or hinders their learning.

The current literature on how STEM teachers progress is not quite clear as it is scattered throughout works on teacher training, professional development, teacher identity, and teacher perceptions and attitudes (e.g., Al Salami, Makela, \& de Miranda, 2017; Faber, Hardin, Klein-Gardner, \& Benson, 2014; McIntyre et al., 2013). By looking at past studies on teacher identity, Avraamidou (2014) calls for the need to carry out studies specifically on science teacher identity which are longitudinal and view teacher identity as a process which shows how teachers develop in different contexts. Mewborn (2002) carried out a longitudinal study on an elementary mathematics teacher for a period of 4 years, ranging from when she started taking her mathematics methods class up until the second year of her teaching. With the help of Green's (1971) explanation of belief systems and Dewey's (1933) reflective thinking which consists of open-mindedness, wholeheartedness, and responsibility, Mewborn realized that over time, the study's participant identified, analyzed, and solved inconsistencies in her beliefs through reflective thinking. She was seen to shape her thoughts to resemble the ideal belief system laid out by Green (1971) which consists of a combination of different types of beliefs.

Carrier, Whitehead, Walkowiak, Luginbuhl, and Thomson (2017) studied two science teachers in a longitudinal project over 3 years which included their teacher preparation years and their first year of teaching at an elementary level. To do this, they started with three stages of student, teacher candidate, and teacher. Inside these three stages, they studied Gee's (2000) identity constructs which are nature (background influences), institution (influences of institutions on identity), discourse (influences of conversations with others), and affinity (influences of communities). Themes that emerged which affected these identities of participants in their journeys from students to teachers were memories related to science and science instruction, STEM-centered program, experiences gained in the field, teaching in the first year, and opinions held on what good science teaching consists of.

STEM education initiatives in informal settings have many proponents because of their potential to enhance STEM learning without standard curriculum pressures (National Research Council, 2009; Peppler, 2017). However, informal STEM education is a narrower subcategory of STEM education in general, and this means there are even scarcer resources on how teachers develop their identities in such environments. Research shows that informal STEM settings benefit teacher professional development by improving their STEM literacy (Jackson \& Mohr-Schroeder, 2018), encouraging them to try new teaching methods, and enhancing their classroom-relevant competencies such as creativity, social skills, and leadership (Terrazas-Marín, 2018). But longitudinalnatured studies which specifically show how teachers progress in such environments and how their identities are shaped are rare. Through semi-structured interviews with secondary school teachers who participated in informal STEM outreach activities with their students, Aslam, Adefila, and Bagiya (2018) realized that these activities provided teachers with opportunities to interactively and transformatively co-learn alongside their students and deeply reflect on their teaching practices which resulted in a 
strengthening of their own identities as STEM professionals. Adams and Gupta (2017) show that teacher candidates who work in informal science institutions progress and develop their professional identities by using the informal settings' flexibility and opportunities to link practice to theory, develop improvisation skills, and imagine themselves in the future. The existing studies on teacher learning and progress in informal settings focus on pre- or in-service teachers who have undergone or are currently undergoing formal teacher education and how being in informal settings can complement their skills for a formal educational setting, whereas many teachers in informal settings are not required to have had formal training. Studies which do observe informal teachers who did not necessarily go through formal teacher education do not necessarily emphasize teacher progress. Koch and Gorges (2016) studied several women STEM facilitators working in an informal setting who came from different educational backgrounds and interests. Although their work did not focus on how these facilitators developed as teachers, it did show how they had all experienced a level of professional growth and developed their STEM identities because of the STEM course they had taught. Their research participants mentioned that learning from the curriculum they had in hand, putting it into practice, and working in an encouraging environment had influenced them to continue work in STEM-related fields by resuming to teach in the field or moving on to other STEM careers. Participants' confidence and interest in STEM was also reported to increase.

To address the substantial gap in existing literature where there is not much known on informal STEM educators' progress who have not undergone the usual teacher training others have undergone, this study set out to follow the natural progress of one such STEM teacher in her very first informal STEM class. The study was guided by this research question: What are the learning progressions of one STEM teacher in an informal setting?

\section{Theoretical framework}

To answer our research question, this study uses the "self-authorship" framework developed by Baxter Magolda (2004). Kegan (1994) first developed the basis of this framework by breaking down the personal evolution of adults' meaning making into three stages of socialized, self-authoring, and self-transforming. In the first stage, one's environment defines them, and they constantly seek approval from others. In the second stage, one can assess others' opinions using their own views. This refers to one's capability to internally make meanings, as opposed to externally, when faced with various environmental and relational expectations. The last and rarest stage to reach is the self-transforming stage where one can look at all beliefs from the outside and be open to ideas.

Building on Kegan's (1994) work, Baxter Magolda (2004) created an identity development framework (see Fig. 1) consisting of four stages (in three dimensions) which we will be using in this study.

The first stage is the "Following Formulas" stage in which a person looks for external signals as guidance for actions and decisions and lacks an "internal voice." Or in other words, "external voices (those of others) in the foreground drown out [the] internal voice" (Baxter Magolda, 2009, p. 4). The dissatisfaction of this blind imitation or complete adherence to others' views leads one to the second phase which is the 


\begin{tabular}{|c|c|c|c|c|}
\hline & Following Formulas & Crossroads & $\begin{array}{l}\text { Becoming } \\
\text { the Author of One's life }\end{array}$ & Internal Foundation \\
\hline $\begin{array}{l}\text { Epistemological } \\
\text { dimension: } \\
\text { how do I know }\end{array}$ & $\begin{array}{l}\text { Believe authority's } \\
\text { plans; how } \\
\text { "you" know }\end{array}$ & $\begin{array}{l}\text { Question plans; } \\
\text { see need } \\
\text { for own vision }\end{array}$ & $\begin{array}{l}\text { Choose own beliefs; } \\
\text { how "I" know in } \\
\text { context of external } \\
\text { knowledge claims }\end{array}$ & $\begin{array}{l}\text { Grounded in internal } \\
\text { belief system }\end{array}$ \\
\hline $\begin{array}{l}\text { Intrapersonal } \\
\text { dimension: } \\
\text { who am I? }\end{array}$ & $\begin{array}{l}\text { Define self through } \\
\text { external others }\end{array}$ & $\begin{array}{l}\text { Realize dilemma of } \\
\text { external definition; see } \\
\text { need for internal identity }\end{array}$ & $\begin{array}{l}\text { Choose own values, } \\
\text { identity in context of } \\
\text { external forces }\end{array}$ & $\begin{array}{l}\text { Grounded in internal } \\
\text { coherent sense of self }\end{array}$ \\
\hline $\begin{array}{l}\text { Interpersonal } \\
\text { dimension: } \\
\text { what relationships } \\
\text { do I want with } \\
\text { others? }\end{array}$ & $\begin{array}{l}\text { Act in relationships } \\
\text { to acquire approval }\end{array}$ & $\begin{array}{l}\text { Realize delemma of } \\
\text { focusing on external } \\
\text { approval; see need to } \\
\text { bring self to } \\
\text { relationship }\end{array}$ & $\begin{array}{l}\text { Act in relationships } \\
\text { to be true to self, } \\
\text { mutually negotating } \\
\text { how needs are met }\end{array}$ & $\begin{array}{l}\text { Grounded in } \\
\text { mutality }\end{array}$ \\
\hline & & $\longrightarrow$ & $\longrightarrow$ & $\longrightarrow$ \\
\hline
\end{tabular}

"Crossroads" stage. In this stage, one realizes that they have ignored their own desires for too long. Constantly following others brings about problematic results, and the need arises to include oneself in decisions as well as others. At this point, self-value gradually gains importance in what one believes in and does, and this slowly paves the way for the next phase. The third stage is "Becoming the Author of One's Own Life" and consists of one realizing that they can and want to create their own ideas. This also means that they now shape their own identity as well, along with their social relations. In other words, they are now the ones deciding for their lives. After experiencing this stage for some time, one can possibly move to the fourth and final phase which is the "Internal Foundation" stage. In this stage, one finally feels as if they have control over their life and external factors as opposed to being controlled by them. The self-focus that exists does not come from selfishness, but it is through the comprehensive consideration and evaluation of others' viewpoints and relevant context that the last two stages appear in one's life.

The three dimensions of epistemological (how we know), intrapersonal (how we see ourselves), and interpersonal (how we create our relationships) contribute to this development. An older study on college students' epistemologies by Baxter Magolda (1992b) was also in line with this framework as it showed that students initially start out with an absolute knowing, where they believe all authorities say is true and certain. Then, they move on to transitional knowing and realize that some knowledge is not certain, and finally reach independent knowing where they come to believe most knowledge is not certain. An even more advanced stage where students rarely reached is the contextual knowing stage where knowledge is evaluated based on the existing context. These stages of knowing can be seen as parallel to the identity development stages mentioned above.

Baxter Magolda (2004) initially developed the self-authorship framework to show how college students' identities developed throughout their college years. The various stories which have shaped this framework during and after one's college years (from ages 18 to 45) show how each person's journey can be unique and the strengthening of one's internal voice can happen at different ages and in different contexts (Baxter Magolda, 2009). This personal identity framework which has been able to support such a vast age range for adults has proven to be quite adaptable as it has been used for professional identity development (Hunter, Laursen, \& Seymour, 2007; Nadelson et al., 2017) as well and for other groups such as college educators (Gunersel, Barnett, \& Etienne, 2013). When speaking of 
favorable collegiate outcomes, King and Baxter Magolda (2005) introduced three levels (initial, intermediate, and mature) of intercultural maturity which show how individuals learn to act and understand in interculturally appropriate ways. Later on, when studying possible enhancements of educator's experiences, intercultural maturity was again mentioned with each level of it corresponding to one of the self-authorship framework stages (Baxter Magolda, 2014). The initial level is in line with following formulas, the intermediate level corresponds to the crossroads stage, and the mature level speaks of selfauthorship.

These studies have also shown that people may follow different levels of progress throughout the stages based on the contexts they are in because of the various experiences they have. Here, as we are studying the teacher's natural journey without any formal external support, the stages of following formulas, crossroads, self-authorship, and internal foundation will be used to analyze the data (Baxter Magolda, 2004).

\section{Method and research context}

This study was carried out in the form of a single case study with a single unit (Yin, 2018). The unit of analysis is the teacher, and the data gathered is related to a 6-week reflection and teaching period at a STEM center in Ontario. At the time of the study, the teacher was a 32-year-old PhD student in the field of education with a background in business. The teacher had volunteered at this STEM center since July of 2017 and was then offered to teach a course in February of 2018. Her only teaching experience dated back to her teenage years when she had taught English to young children after her own school hours. During her volunteering period at the center, she had mostly helped with youth robot-making, laser cutting, and coding classes which the center's Director of Education taught. During this time, she became familiar with the teaching environment at the center, learned the kids coding software regularly used for the classes (SCRATCH), and used opportunities to show her graphic design skills which all led to the decision for her to teach her own course. The teacher's STEM class was a four-session graphic design and game development course held in this informal setting over the period of 5 weeks (one session a week, with 1 week in between sessions three and four when no class was held) (see Table 1). During this time, the teacher is in direct and constant contact with the center's Director of Education who, apart from teaching classes, spends a lot of his time developing the center's spaces, settings, and curricula to accommodate students from all age groups, especially ages 6 to 12. He is also one of the founders of this nonprofit STEM center which was established in 2016. During most of our participant's classes, the director was more or less present in the class to monitor her teaching, give her guidance, and offer students complementary information when needed. This graphic design and game development course was a course catered towards ages 6-12 and had been previously taught by the director himself. As a result, the director suggested a number of graphic design software which could be used for the classes, but also gave the teacher freedom to choose other options. No lesson plan existed for what had previously been taught, and expectations for course content were flexible, as long as some "graphic design" and "game development" were covered with a tangible final result to show the parents.

Since the progress of the teacher was important to us, we coded the data based on challenges the teacher was facing and solutions taken up for those specific challenges 
Table 1 Participant's Overall Final Course Layout

\begin{tabular}{|c|c|c|c|c|}
\hline Date & Game element & Graphic design topics covered & $\begin{array}{l}\text { Coding/SCRATCH topics } \\
\text { covered }\end{array}$ & $\begin{array}{l}\text { Other topics } \\
\text { covered }\end{array}$ \\
\hline $\begin{array}{l}21 / \\
02 / \\
2018\end{array}$ & $\begin{array}{l}\text { 2D character } \\
\text { designed in Gravit }\end{array}$ & $\begin{array}{l}\text { Drawing shapes, coloring, } \\
\text { different selection tools, layers, } \\
\text { editing path, etc. }\end{array}$ & $\begin{array}{l}\text { Simple looks codes } \\
\text { (costumes), sounds (say), } \\
\text { control (wait), events (green } \\
\text { flag or if } x \text { key is pressed), } \\
\text { etc. }\end{array}$ & $\begin{array}{l}\text { Imagination, } \\
\text { problem solving, } \\
\text { reasoning }\end{array}$ \\
\hline $\begin{array}{l}28 / \\
02 / \\
2018\end{array}$ & $\begin{array}{l}\text { 2D character } \\
\text { designed in } \\
\text { Piskelapp and 3D } \\
\text { character in } \\
\text { Magicavoxel }\end{array}$ & $\begin{array}{l}\text { Piskelapp: drawing shapes, } \\
\text { symmetric drawing, cut/copy/ } \\
\text { paste, gif, etc. } \\
\text { Magicavoxel: different brushes } \\
\text { (attach, erase, and paint for } \\
\text { each), eye dropper, templates, } \\
\text { canvas size, etc. }\end{array}$ & $\begin{array}{l}\text { Simple motion codes } \\
\text { (moving, go to), More } \\
\text { complicated controls (if/then, } \\
\text { repeat), etc. }\end{array}$ & $\begin{array}{l}\text { Collaboration, } \\
\text { problem solving, } \\
\text { reasoning, } \\
\text { perspective taking/ } \\
\text { empathy }\end{array}$ \\
\hline $\begin{array}{l}07 / \\
03 / \\
2018\end{array}$ & $\begin{array}{l}\text { Background } \\
\text { designed in } \\
\text { MyPaint with a } \\
\text { graphic tablet }\end{array}$ & $\begin{array}{l}\text { Shortcut keys on tablet, } \\
\text { different brushes, pressure } \\
\text { sensitivity, tracing images, } \\
\text { layers, scrap page, etc. }\end{array}$ & $\begin{array}{l}\text { Similar to first two sessions } \\
\text { plus variables and clones }\end{array}$ & $\begin{array}{l}\text { Tracing/modeling, } \\
\text { problem solving, } \\
\text { reasoning }\end{array}$ \\
\hline $\begin{array}{l}21 / \\
03 / \\
2018\end{array}$ & $\begin{array}{l}\text { Character (picture } \\
\text { of themselves in } \\
\text { SCRATCH) }\end{array}$ & $\begin{array}{l}\text { Understanding the green } \\
\text { screen concept, using magic } \\
\text { wand and eraser in SCRATCH } \\
\text { to cut their own picture out }\end{array}$ & $\begin{array}{l}\text { Modifying existing codes, } \\
\text { repeat until, operators, more } \\
\text { complicated looks, sound, } \\
\text { and motion codes }\end{array}$ & $\begin{array}{l}\text { Imagination, bodily } \\
\text { expression, } \\
\text { mathematics }\end{array}$ \\
\hline
\end{tabular}

throughout the sessions. Inside these categories, an inductive approach was taken using open and axial coding (Creswell, 2007) to find emergent patterns. During this process, we realized our data was in line with Baxter Magolda's (2004) self-authorship framework and decided to reanalyze our data with it.

To better adapt this framework (Fig. 1) to our study, two minor modifications were made. First, in the following formulas stage and at the epistemological dimension, "Believe authority's plans; how 'you' know" was changed to "Believe authority's plans and other knowledge sources; how 'you' know." And in the same stage, at the interpersonal dimension "Act in relationships to acquire approval" was modified to "Search for or act for approval in relationships." Then, a code was created for each of the dimensions of each stage (e.g., believe authority's plans and other knowledge sources, define self through external others, search for or act for approval in relationships, etc.), resulting in 12 a priori codes. We then went through our available data using these codes while also marking each piece of coded data in our overall time frame (Fig. 2). For example, "I spent much of today again playing around with Mypaint which I told Fred I want to use for next session..." (March 3, 2018) was given two codes. The first code was "Choose own beliefs" because MyPaint was a software the teacher had personally decided to use and was different from the software initially suggested to her by the director. And the second code was "Act in relationships to be true to self, mutually negotiating how needs are met" because the teacher normally looked for approval from the director, but here, she shows that she was the one who strongly promoted the use of this software to be used.

According to Lincoln and Guba (2013), data triangulation, peer debriefing and member checks, and process and data audits were used for trustworthiness. For triangulation, the teacher's journal was used alongside teacher-designed lesson plans and teacher artifacts (designed characters, backdrops, coding and visuals of games, etc.). Before the analysis, the choice of method, and after the analysis, the codings were sent to an impartial colleague for peer debriefing. Findings were discussed with the teacher 


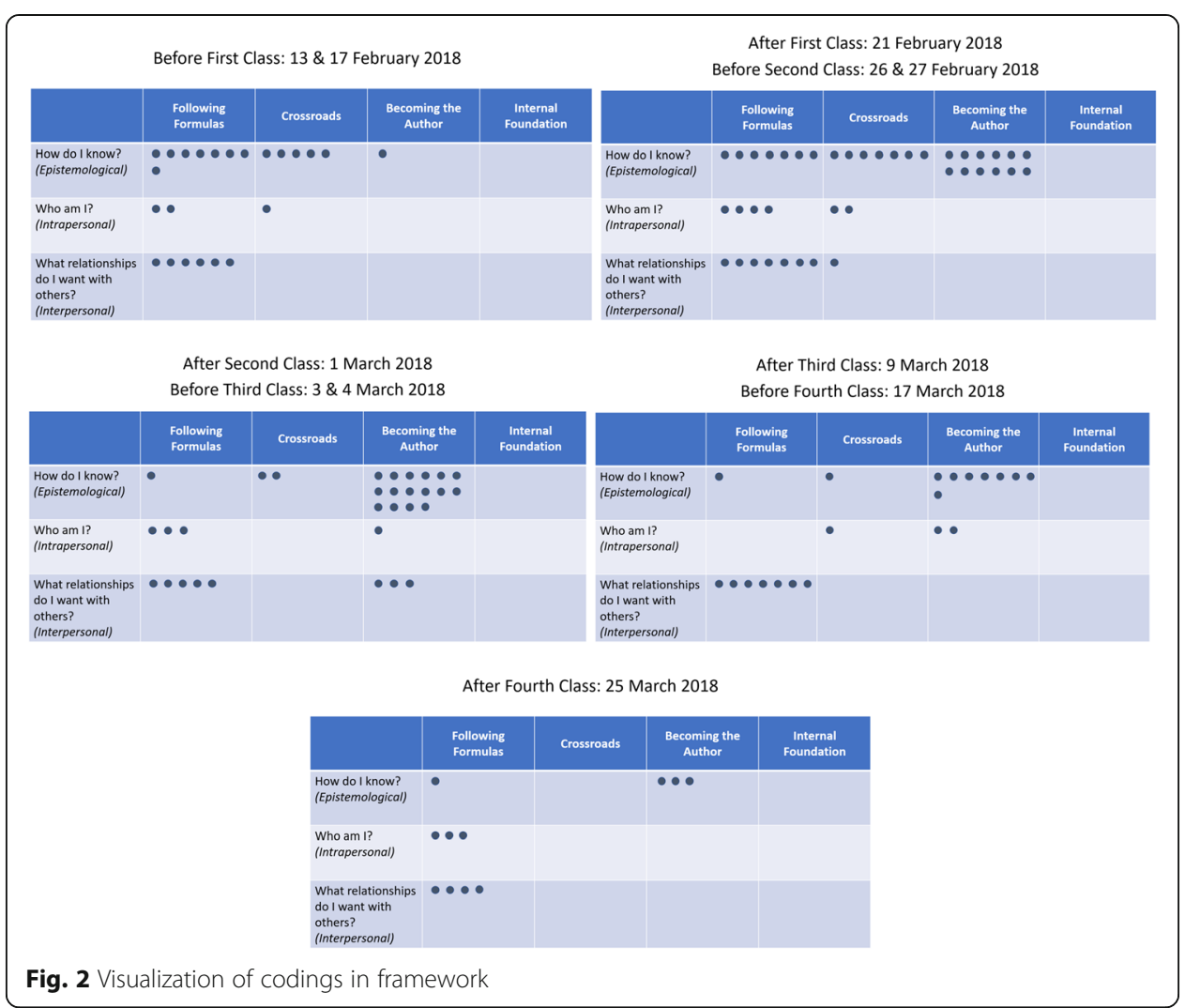

participant at two stages to confirm accordance of our work with the teacher's experience. The same colleague who had supported us for peer debriefing and was well aware of our methodological approach also performed our process and data audits and provided us with continuous feedback throughout the work.

The content and teaching methods used by the teacher make up the epistemological dimension of the framework, the way she sees herself as a teacher is the intrapersonal dimension, and her relationships with the director, students, and students' parents make up the interpersonal dimension of the framework. We would like to acknowledge that this framework is usually studied with the help of many interviews and over long periods of time whereas our study only covers a 6-week period. However, as mentioned above, our data pointed us towards this framework and we clearly saw value in assessing this compatibility.

\section{Findings}

We found that the progress the teacher in our study shows is in line with Baxter Magolda's (2004) self-authorship framework. As indicated in Fig. 2, the teacher starts clearly in the following formulas stage and gradually moves towards self-authorship in a nonlinear way, with the most distinct change visible over time in the epistemological dimension. A total of 125 codes were created: $58.4 \%$ of the codes related to the epistemological dimension, $15.2 \%$ referred to the interpersonal dimension, and $26.4 \%$ referred to the intrapersonal dimension. 


\section{First class}

The teacher's journal shows a complete lack of internal voice in the initial entry, which starts improving substantially in the following entries. She was knowledgeable in the contents of the course, but it was the first time she was going to design and teach a STEM class. She asked the Director of Education for some ideas in an email and received a reply. In her initial journal entry, she noted "Based exactly on his email, I started to create a lesson plan" (February 17, 2018). Once finished, she wrote "Even though he [the director] didn't ask, I showed it all to him and we chatted about it online" (February 17, 2018). Apart from her believing in the director's knowledge (epistemological), it was seen that she showed the director her work in hope of receiving approval (interpersonal) even though it was not asked of her.

Before the class, she also wondered about herself as a teacher (interpersonal) by writing "What if I'm not what he [the director] expects me to be? But I should be because he has seen me in class and so if he thinks I can, I should be able to" (February 17, 2018). She included an idea of her own but left it out from the lesson plan to ask for the director's opinion on it. This complete following of others and adherence to imagined or real expectations continued until the first class had been held. The positive experience of the first class along with the approval and support she received from the director pushed her to give more weight to her own content knowledge and ideas for the second class.

\section{Second class}

Before the second class, she showed signs of being in the crossroads stage by revising the next session's lesson plan with small ideas of her own in a red-colored font and with question marks which she did not check with the director this time (see Fig. 3). This shows that she sees the need to bring in her own views without necessarily checking them with an authority, but still they are in red and accompanied with question marks which show her lack of confidence to act on her views without approval.

Right before the second class, she decided firmly to bring in her own idea as a centerpiece which shows her need to include her own knowledge. But at the same time, her own idea was the same idea that she had proposed to the director before the first session and had gotten positive feedback on. She wrote "...this time I'll be doing the activity I initially proposed in the last page of the lesson plan which [the director] said he liked" (February 27, 2018) which illustrates a tendency to epistemologically move towards self-authorship and trust her knowledge while still heavily relying on epistemological, intrapersonal, and interpersonal approval and guidance from other sources. Her constant lookout for satisfaction among students and their parents also showed this need for approvals. For example, she mentioned "In the end the student's family came in and spoke to the director and wrote down the names of the apps we were working with. They seemed to like the class and the software we were working with" (March 1, 2018).

\section{Third class}

Similarly, gradual change can be seen as we move forward throughout the weeks. For the third session, the teacher decided on new content and new software which was different from what the director had suggested. The director had purchased graphic tablets after 


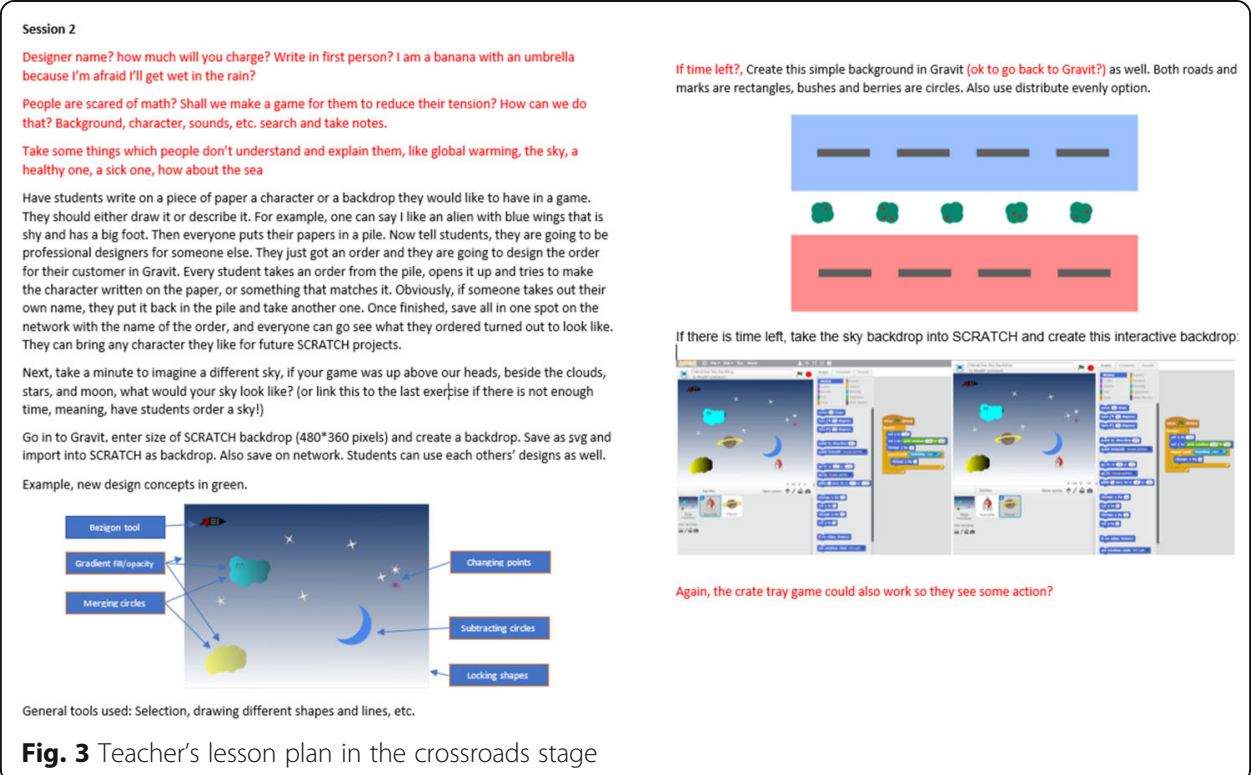

the first class and asked our teacher participant to add the use of these tablets to one of the sessions. He also suggested the teacher use the tablets with the Sculptris software, to create 3D characters. The teacher disagreed because she noticed that her students had already been making characters for the last two sessions and wanted to provide a new experience for them, so after careful consideration of a handful of software, she proposed to make a backdrop or a different element for the third session using a new software (MyPaint). The teacher started to recognize and communicate what she wanted to teach and do in class as opposed to what had been suggested to her so far (epistemological). Also, for the first time, she was confident in herself (interpersonal) and was negotiating with the director for her decisions (interpersonal) which were the strongest signs of progression through the framework seen up to this point.

\section{Fourth class}

For the fourth session, again she inserted new ideas in the lesson plan but without any question marks or red colors. She did not consult the director regarding her plans and wrote both in her journal and lesson plan in a more assertive manner compared to her initial entries. She also expressed she is more comfortable to joke around with students and have a good time. Instances like these point to her progress towards self-authorship in the epistemological and intrapersonal dimensions as she starts trusting her identity as a teacher and her decisions on what to teach. This level of self-authoring was seen most in the epistemological dimension towards the end. However, when it came to relationships and other people's expectations, she was still constantly concerned about approvals and how her actions were seen by the director, students, and parents, even after the last class. Figure 2 shows a visual representation of how during the weeks, the codings move through the identity stages of the framework. 


\section{Interweaving and interdependence of dimensions}

Some data adhered to the framework but were not easily codable into one specific section of Fig. 1, or they simultaneously adhered to different sections of the framework. As Baxter Magolda (2004) had also concluded, this showed a clear interweaving of the three dimensions of the framework. The interpersonal code relating to the following formulas stage titled "Search for or act for approval in relationships" overlapped with 16 epistemological and 14 intrapersonal codes. In the initial sessions, the teacher only looked to teach the director's suggestions or what he had approved of. This shows her beliefs about knowledge and herself as a teacher depended completely on her relationship with the director. This dependence of the intrapersonal and epistemological dimensions on the interpersonal dimension stayed visible throughout all the sessions (See Fig. 2).

In her second entry once again, she showed how she made her teaching decisions based on the feedback she received from the director:

Then, although I had not initially planned this out from last week, since [the director] gave me good feedback on the lesson plan regarding the order giving section, I took the liberty of incorporating imagination a bit more here as well so I took them [students] to sit in a corner away from the computers and did an imagination activity, where they closed their eyes and imagined a place where rain falls from purple and orange clouds, but the raindrops are not water (February 21, 2018).

Moving forward, she starts to realize what kind of a teacher she wants to be, but she is still burdened by the presence of others when they are there.

I feel more confident now when teaching. I think. Or maybe I'm saying this because the session on March 4th, I was alone more. Holly was not there as a volunteer, and [the director] came in late and would go and come back more than usual (March 9, 2018).

Apart from her relationship with those in the center, her relationship with the students and parents also shaped how she decided to act and see herself as a teacher. The following quote refers to when the teacher believed in what she had taught and how she had taught it, but she was still afraid of the father's judgement and shaped the rest of her actions differently because of the parent's presence. This separation of beliefs and actions is also a characteristic of the crossroads stage:

So when he [student's father] came in at around 6:15 pm, my activity was done, and they were simply playing around with the code and designs so I was afraid that he'd think we were simply wasting time and not doing much. So, I decided to go to the students' sides one by one to see what they are doing and try to help them expand their ideas and I hope it didn't look bad. (March 25, 2018)

The very last sentence of her journal after the last class points to the link she saw between her being a good teacher and what she felt the students thought: "Overall I'm satisfied with the class and myself as a teacher and I know the students were too" (March 25, 2018).

As mentioned, there were many instances throughout our data where the epistemological and intrapersonal dimensions depended on the interpersonal, but we were also able to occasionally see the opposite. When the director added the graphic tablet to the teacher's teaching agenda is where the interpersonal dimension depended on the other two dimensions. After the teacher participant was given the tablet, she downloaded a number of software and spent many hours testing them out, while also learning to 
work with the tablet herself. Once she had gained enough knowledge in the area, she gained her own opinion on what she wanted to teach, how she wanted to teach it, her reasons for her choices, and also what software she thought was best for the students. This epistemological and intrapersonal progress was what empowered her to disagree with the director and negotiate her requests and beliefs instead.

These instances all reinforce the interconnections of dimensions and show how improvements in one can affect the other.

\section{Discussion}

This study expands the literature on informal STEM teacher progress by recognizing its adaptability to the self-authorship framework. Different from research that studies teachers' experiences while relating them to a specific teacher professional development or teacher education program (Al Salami et al., 2017; Faber et al., 2014; Glavich, 2016), this study observes the natural pathway a novice informal STEM teacher follows in the environment she is placed in without any preplanned support. As mentioned above, the observed development resembled the self-authorship framework (Baxter Magolda, 2004). This framework has a complex and cyclical nature, so moving through the stages does not necessarily translate into following a linear path (Baxter Magolda, 2008).

This is seen in this case (see Fig, 1) as the teacher of our study clearly starts in the following formulas stage but constantly shows elements of moving forward up until the self-authorship phase while simultaneously moving back to the initial phase. The existence of a code related to a stage does not necessarily indicate that the participant is in that stage. Successfully reaching self-authorship requires doing so in all three dimensions, and this does not happen for our teacher which is quite natural given the short duration of this study and the time needed for one to grow into self-authorship. However, we believe that the slow but existing progress and adherence of data to the framework indicate that if this study were to continue to study the teacher's progress in her next classes, she would have moved into the self-authorship and internal foundation stages over time.

Baxter Magolda's (1992a) initial study on college students showed the question of "what and how one knows" is more dominant for those in the initial phases of the framework. But this same study also guesses that this was because of the nature and framing of the study at that point in time. As our case duplicates this finding, we see three potentials hypotheses. First, possibly, those in the initial stages are actually in general more occupied with the epistemological dimension; second, it can be a result of the teacher focusing on the epistemological dimension because of the curriculum designing task she had taken on; or third, there may have coincidentally been more data on this dimension for us to explore.

Similar to Baxter Magolda's (1992b) college students, our teacher started as an absolute knower (believing in absolute forms of knowledge) and gradually moved towards independent (believing in oneself along authority) beliefs. Issues arising from blind following lead to a quick stage change at first, but it is not permanent as moving into selfauthorship and contextual knowing requires much more time. We believe with the passing of time, the teacher would also move towards contextual beliefs about knowledge where one considers the context, expert knowledge, and self-knowledge simultaneously when making decisions. 
The self-authorship framework also uses Kegan's (1994) notion of the subject-object relationship. According to Kegan, an object is an element which we can stand apart from and reflect on while a subject is something which is part of us and we have no control over. In this study, the teacher showed that in the beginning of her journey, she saw her teacher role as a subject and as a subcategory of the director and others' expectations with no room for change. Her role was part of who she was; therefore, it was fixed. Over time, she was able to move her role from a subject position to an object one, where she was able to look at it from the outside, reflect on it, and influence it.

The importance of continuously looking for and receiving approvals and supports was seen in all the developmental stages of the framework until the very last entry of the journal. The three dimensions are deeply interwoven with the epistemological and intrapersonal ones specifically reliant on the interpersonal dimension. It is external expectations and the approvals and support the teacher received from others (students, director, and parents) that concern her while at the same time giving her courage to move forward and make decisions about what to believe in and what to do. We believe this is in line with literature that emphasizes the importance of collaboration opportunities (Fulton \& Britton, 2011) and mentoring programs (Andrews \& Quinn, 2005) for novice STEM teachers as they are able to provide support and nonthreatening feedback to teachers (Brighton, 1999).

Another point which became evident in this study and can be fruitful for teachers of all subjects is that much of the progress that took place towards self-authorship was during the teacher's involvement in the curriculum designing process. This process provided much opportunity for reflection and self-reflection which are closely linked to the intrapersonal level of self-authorship (Baxter Magolda, 2004). This also contributes to studies which call for the involvement of teachers in curriculum creation for the purpose of teacher professional development. Ball and Cohen (1996) believe that when a curriculum is developed/designed by a teacher with a focus specifically on enactment, it will enhance teacher learning because of the following interconnected domains it covers: first, what teachers think about their students and what their students bring to the class; second, what teachers think about the material and how they use this understanding; third, how teachers customize the material for their students; fourth, how the class environment affects everything; and fifth, how teachers' views on broader contexts influence the curriculum. Curriculum development is also promoted for teacher professional development in the form of group activities and in networks (Coenders, Terlouw, Dijkstra, Pieters, \& Pieter, 2010; McFadden \& Roehrig, 2017). However, this study points to the benefits of individual curriculum development as well which is known to increase teacher confidence and reflection (Valli, 1992). In our informal STEM teacher's case, this individual curriculum development helped move the teacher through the selfauthorship identity stages through constant reflection.

Similar to the positive effects of participating in curriculum design, we believe the technology-based nature of the subject which our teacher participant taught also created many opportunities for her to reflect on her work and be pushed towards a quicker progression through the self-authorship framework, especially in the epistemological and intrapersonal dimensions. As pointed out at the beginning of this paper, technology is constantly changing, and this means much effort is required if teachers are to stay up to date on the newest and most appropriate options available. For example, when the center 
director added the use of graphic tablets to the teacher's agenda, this was quite a big challenge and modification for our teacher participant as she had already preplanned her sessions. She put quite a lot of time and effort into studying available software and choosing the proper one. This process entailed much reflection on herself as a teacher, her students, and her practice. Such changes are very common for those who teach technology-based subjects or regularly use technology in their teaching practice. If educators are to be adaptable, deliberation will be inevitable, and reflection is clearly critical in teacher professional development and progress (Postholm, 2008; Wang, 2017). This technologyenhanced learning which took place for our teacher participant is very well in line with literature that studies the technology selection process that teachers go through and the criteria they consider when doing so. For example, Ocak and Baran (2019) studied primary and secondary school science teachers and saw that they considered adaptability to science content, students' needs, and the features of the technology during their selection process. Haugland (1999) also points out 10 criteria for technology selection for young children which include age appropriate, child in control, clear instructions, expanding complexity, independence, nonviolence, process orientation, real-world model, technical features, and transformation. Choosing what software to use (and how to use it) among the myriad of available options is no simple and straightforward task for the teacher and will require much deliberation which can help enhance teacher learning and progress. We will also add that a well-known barrier to technology use is a negative belief or attitude towards it (Mama \& Hennessy, 2013). The fact that our teacher participant was a STEM teacher meant that she already had a positive attitude towards technology use and welcomed the changing nature of it which led to more thoughtful and open-minded reflections. Our teacher participant also had flexibility and enough time to indulge in these reflections because she was an informal STEM teacher who was not under the pressure of carrying out a specific curriculum.

\section{Conclusion}

The importance of STEM education has inevitably led to a range of studies on STEM educators. Informal STEM settings which are widely used to generate motivation in students (Aslam, Adefila, \& Bagiya, 2018; Ayar, 2015) also call for the study of educators specifically in such environments. Because of existing research and evidence relating to teacher development pathways, there is a better view of those coming to the classroom through a standard pipeline as opposed to educators who have not experienced such a conventional journey to STEM teaching. This study set out to follow the natural progress of a novice STEM teacher who had not undergone any teacher education. The resulting data pointed us towards Baxter Magolda's (2004) self-authorship framework. Although this framework was developed to explain the experiences of college students from their early college years until after their studies, it also showed a reasonable compatibility with the experience of our novice STEM teacher participant. This resemblance does not come as a surprise to us as they both have one's natural progress and identity development in mind. In line with this study and with other studies which have linked the self-authorship framework to other demographic groups (Gunersel, Barnett, \& Etienne, 2013) and to professional identity development instead of personal identity development (Nadelson et al., 2017), we suggest further research should be done to study more STEM teachers who have similarly not undergone 
teacher education to see if the same results emerge, in addition to teachers who have undergone such education to see if those who have had a standard support system follow a similar pathway or not.

The adaptability of the self-authorship framework to our informal STEM teacher's progress, as well as to college students, university science students, and college educators (Baxter Magolda, 2004; Gunersel, Barnett, \& Etienne, 2013; Nadelson et al., 2017), signals the development of human nature in general. This means skills linked to the stages of self-authorship and internal foundation could come in handy for teachers regardless of the subject they teach, skills such as being able to have one's own voice when it comes to deciding what to do and how to act in social relations. Further research can also shed light on how this framework would work for teachers who have went through the framework for one subject but start teaching a different subject for the first time. For example, if a STEM teacher reaches the self-authorship or internal foundations stage in their work after some time and one day they decide to start to teach History, will the stages have to be gone through all over again? Or will it be different this time because of some of the mentality which was previously shaped when the teacher was teaching STEM? Is any part of this framework transferrable?

We would like to acknowledge that our study was not free from limitations and challenges. As our initial intention was not the analysis of our data based on the selfauthorship framework, our data and the framework do not have an ideal match. For example, some days the teacher's journal entry was very short, offering us limited information on the teacher's mindset and the different dimensions of the framework while some days entries were much longer with plenty of room for insight and this caused an imbalance in the amount of data available to code by date. The timeline of the study was also short for an identity development study, and although all data sources were used and coded, the journal data source became dominant. This study advances the literature on the informal STEM teachers' identity development and progress by recognizing its compatibility with the self-authorship framework. It also stresses the importance of teacher support initiatives which involve collaboration, mentoring, and curriculum design which can help support an informal STEM teacher in their journey.

Authors' contributions

All authors read and approved the final manuscript.

Funding

We are grateful for the support from Social Science and Humanities Research Council of Canada and University of Western Ontario in funding this project.

Competing interests

The authors declare that they have no competing interests.

Received: 12 February 2019 Accepted: 1 July 2019

Published online: 01 August 2019

\section{References}

Adams, J. D., \& Gupta, P. (2017). Informal science institutions and learning to teach: An examination of identity, agency, and affordances. Journal of Research in Science Teaching, 54(1), 121-138. https://doi.org/10.1002/tea.21270.

Al Salami, M. K., Makela, C. J., \& de Miranda, M. A. (2017). Assessing changes in teachers' attitudes toward interdisciplinary STEM teaching. International Journal of Technology and Design Education, 27(1), 63-88. https://doi.org/10.1007/s10798015-9341-0.

Andrews, B. D. A., \& Quinn, R. J. (2005). The effects of mentoring on first-year teachers' perceptions of support received. The Clearing House: A Journal of Educational Strategies, Issues and Ideas, 78(3), 110-116. https://doi.org/10.3200/TCHS.78.3.11 $0-117$.

Aslam, F., Adefila, A., \& Bagiya, Y. (2018). STEM outreach activities: an approach to teachers' professional development. Journal of Education for Teaching, 44(1), 58-70. 
Avraamidou, L. (2014). Studying science teacher identity: current insights and future research directions. Studies in Science Education, 50(2), 145-179. https://doi.org/10.1080/03057267.2014.937171.

Ayar, M. C. (2015). First-hand experience with engineering design and career interest in engineering: An informal stem education case study. Educational Sciences: Theory and Practice, 15(6), 1655-1675.

Ball, D. L., \& Cohen, D. K. (1996). Reform by the Book: What is—or might be-the role of curriculum materials in teacher learning and instructional reform? Educational Researcher, 25(9), 6-14. https://doi.org/10.3102/0013189X025009006.

Baxter Magolda, M. B. (1992a). Knowing and reasoning in college: Gender-related patterns in students' intellectual development. San Francisco: Jossey-Bass.

Baxter Magolda, M. B. (1992b). Students' epistemologies and academic experiences: Implications for pedagogy. The Review of Higher Education, 15(3), 265-287.

Baxter Magolda, M. B. (2004). Making their own way: Narratives for transforming higher education to promote self-development. Sterling, Virginia: Stylus Publishing, LLC.

Baxter Magolda, M. B. (2008). Three elements of self-authorship. Journal of College Student Development, 49(4), 269-284. https://doi.org/10.1353/csd.0.0016.

Baxter Magolda, M. B. (2009). Authoring your life: developing an internal voice to navigate life's challenges (1st ed.). Sterling, Va: Stylus Pub.

Baxter Magolda, M. B. (2014). Enriching educators' learning experience. About Campus, 19(2), 2-10. https://doi.org/1 $0.1002 / a b c .21150$.

Brighton, C. (1999). Keeping good teachers: Lessons from novices. A better beginning: Supporting and mentoring new teachers, 197-201.

Carrier, S. J., Whitehead, A. N., Walkowiak, T. A., Luginbuhl, S. C., \& Thomson, M. M. (2017). The development of elementary teacher identities as teachers of science. International Journal of Science Education, 39(13), 1733-1754. https://doi.org/10.1 080/09500693.2017.1351648.

Coenders, F., Terlouw, C., Dijkstra, S., Pieters, J., \& Pieter, J. (2010). The effects of the design and development of a chemistry curriculum reform on teachers' professional growth: A case study. Journal of Science Teacher Education, 21(5), 535-557. https://doi.org/10.1007/s10972-010-9194-z.

Creswell, J. W. (2007). Qualitative inquiry \& research design: choosing among five approaches (2nd ed.). Thousand Oaks: Sage Publications.

Dewey, J. (1933). How we think: A restatement of the relation of reflective thinking to the educational process. Lexington, MA: Heath.

Du, W., Liu, D., Johnson, C. C., Sondergeld, T. A., Bolshakova, V. L. J., \& Moore, T. J. (2019). The impact of integrated STEM professional development on teacher quality. School Science and Mathematics, 119(2), 105-114. https://doi.org/10.1111/ ssm.12318.

Faber, C., Hardin, E., Klein-Gardner, S., \& Benson, L. (2014). Development of teachers as scientists in research experiences for teachers programs. Journal of Science Teacher Education, 25(7), 785-806. https://doi.org/10.1007/s1 0972-014-9400-5.

Fulton, K., \& Britton, T. (2011). STEM teachers in professional learning communities: From good teachers to great teaching. National Commission on Teaching and America's Future.

Gee, J. P. (2000). Identity as an analytic lens for research in education. Review of Research in Education, 25, 99-125. https://doi. org/10.2307/1167322.

Ghadiri Khanaposhtani, M., Liu, C. J., Gottesman, B. L., Shepardson, D., \& Pijanowski, B. (2018). Evidence that an informal environmental summer camp can contribute to the construction of the conceptual understanding and situational interest of STEM in middle-school youth. International Journal of Science Education, Part B, 8(3), 227-249. https://doi.org/1 $0.1080 / 21548455.2018 .1451665$

Glavich, C. (2016). Growing strong stems reflections of a beginning teacher's preservice program. Issues in Teacher Education, 25(2), 89.

Green, T. F. (1971). The activities of teaching. New York: McGraw-Hill.

Gunersel, A. B., Barnett, P., \& Etienne, M. (2013). Promoting self-authorship of college educators: Exploring the impact of a faculty development program. The Journal of Faculty Development, 27(1), 35.

Haugland, S. (1999). The newest software that meets the developmental needs of young children. Early Childhood Education Journal, 26(4), 245-254. https://doi.org/10.1023/A:1022915706904.

Hunter, A.-B., Laursen, S. L., \& Seymour, E. (2007). Becoming a scientist: The role of undergraduate research in students' cognitive, personal, and professional development. Science Education, 91(1), 36-74. https://doi.org/10.1002/sce.20173.

Jackson, C. D., \& Mohr-Schroeder, M. J. (2018). Increasing STEM literacy via an informal learning environment. Journal of STEM Teacher Education, 53(1), 41-52.

Kegan, R. (1994). In over our heads: The mental demands of modern life. Cambridge, MA: Harvard University Press.

Kim, M. S. (2017). Multimodal modeling activities with special needs children in an informal learning context: Vygotsky Revisited. Eurasia Journal of Mathematics, Science and Technology Education, 13(6), 2133-2154.

King, P. M., \& Baxter Magolda, M. B. (2005). A developmental model of intercultural maturity. Journal of College Student Development, 46(6), 571-592. https://doi.org/10.1353/csd.2005.0060.

Koch, M., \& Gorges, T. (2016). Curricular influences on female afterschool facilitators' computer science interests and career choices. Journal of Science Education and Technology, 25(5), 782-794. https://doi.org/10.1007/s10956-016-9636-2.

Lincoln, Y. S., \& Guba, E. G. (2013). The constructivist credo. Walnut Creek, California: Left Coast Press.

Mama, M., \& Hennessy, S. (2013). Developing a typology of teacher beliefs and practices concerning classroom use of ICT. Computers \& Education, 68, 380-387. https://doi.org/10.1016/j.compedu.2013.05.022.

McFadden, J. R., \& Roehrig, G. H. (2017). Exploring teacher design team endeavors while creating an elementaryfocused STEM-integrated curriculum. International Journal of STEM Education, 4(1), 1-22. https://doi.org/10.1186/s4 0594-017-0084-1.

McIntyre, E., Walkowiak, T., Thomson, M., Carrier, S., Lee, C., Greive, E., \& Difrancesca, D. (2013). A STEM-focused elementary teacher preparation program: Candidate and alumni perceptions (science, technology, engineering, and mathematics). Teacher Education and Practice, 26(4), 670. 
Mewborn, D. S. (2002). Examining mathematics teachers' beliefs through multiple lenses. In Paper presented at the Annual Meeting of the American Educational Research Association. New Orleans, LA.

Milner-Bolotin, M. (2018). Evidence-based research in STEM teacher education: From theory to practice. Frontiers in Education, 3. https://doi.org/10.3389/feduc.2018.00092.

Mohr-Schroeder, M. J., Jackson, C., Miller, M., Walcott, B., Little, D. L., Speler, L., Schroeder, D. C. (2014). Developing middle school students' interests in STEM via summer learning experiences: See Blue STEM Camp. School Science and Mathematics. 114(6), 291-301, https://doi.org/10.1111/ssm.12079.

Nadelson, L. S., McGuire, S. P., Davis, K. A., Farid, A., Hardy, K. K., Hsu, Y.-C., \& Wang, S. (2017). Am I a STEM professional? Documenting STEM student professional identity development. Studies in Higher Education, 42(4), 701-720. https://doi. org/10.1080/03075079.2015.1070819.

National Research Council. (2009). Learning science in informal environments: People, places, and pursuits (0309141133). Retrieved from http://makepuppet.org/after_school/learningScience_inInforalSetting.pdf

Ocak, C., \& Baran, E. (2019). Observing the indicators of technological pedagogical content knowledge in science classrooms: Videobased research. Journal of Research on Technology in Education, 51(1), 43-62. https://doi.org/10.1080/15391523.2018.1550627.

Peppler, K. (2017). The SAGE encyclopedia of out-of-school learning. New York: SAGE.

Postholm, M. B. (2008). Teachers developing practice: Reflection as key activity. Teaching and Teacher Education, 24(7), 17171728. https://doi.org/10.1016/j.tate.2008.02.024

Richmond, G., Dershimer, R. C., Ferreira, M., Maylone, N., Kubitskey, B., \& Meriweather, A. (2017). Developing and sustaining an educative mentoring model of STEM teacher professional development through collaborative partnership. Mentoring \& Tutoring: Partnership in Learning, 25(1), 5-26. https://doi.org/10.1080/13611267.2017.1308097.

Rinke, C. R., Gladstone-Brown, W., Kinlaw, C. R., \& Cappiello, J. (2016). Characterizing STEM teacher education: Affordances and constraints of explicit STEM preparation for elementary teachers. School Science and Mathematics, 116(6), 300.

Terrazas-Marín, R. A. (2018). Developing non-formal education competences as a complement of formal education for STEM lecturers. Journal of Education for Teaching, 44(1), 118-123. https://doi.org/10.1080/02607476.2018.1422613.

Valli, L. (1992). Reflective teacher education: cases and critiques. Albany, N.Y: State University of New York Press.

Waight, N., \& Abd-El-Khalick, F. (2012). Nature of technology: Implications for design, development, and enactment of technological tools in school science classrooms. International Journal of Science Education, 34(18), 2875-2905. https://doi. org/10.1080/09500693.2012.698763.

Wang, T. (2017). Overcoming barriers to 'flip': building teacher's capacity for the adoption of flipped classroom in Hong Kong secondary schools. Research and practice in technology enhanced learning, 12(1), 6.

Wright, D. S., Balgopal, M. M., Sample McMeeking, L. B., \& Weinberg, A. E. (2019). Developing resilient K-12 STEM teachers. Advances in Developing Human Resources, 21(1), 16-34. https://doi.org/10.1177/1523422318814483.

Yin, R. K. (2018). Case study research and applications: Design and methods (6th ed.). Thousand Oaks, California: SAGE.

\section{Publisher's Note}

Springer Nature remains neutral with regard to jurisdictional claims in published maps and institutional affiliations.

\section{Submit your manuscript to a SpringerOpen ${ }^{\circ}$ journal and benefit from:}

- Convenient online submission

- Rigorous peer review

- Open access: articles freely available online

- High visibility within the field

- Retaining the copyright to your article

Submit your next manuscript at $\boldsymbol{s p r i n g e r o p e n . c o m ~}$ 